(C) Н.А. Маничкин

\title{
ДУХОВНОЕ ЦЕЛИТЕЛЬСТВО В АФРО-КУБИНСКИХ РЕЛИГИОЗНЫХ ТРАДИЦИЯХ
}

\begin{abstract}
Статья посвящена духовному ичелительству и терапевтическим иеремониям афро-кубинских религиозных традиций. Особое внимание уделено сложным отношениям последователей культа с духами. В связи с этим рассматриваются обстоятельства и признаки духовного избранничества, связь инициаций и исиеления, а также общие представления об устройстве бытия, которые выступают основой афро-кубинского иелительства. Материалом для статьи служат полевые исследования автора и научная литература, касающаяся затронутых вопросов.
\end{abstract}

Ключевые слова: Куба, спиритизм, сантерия, пало монте, йоруба, иелительство, народная медищина, ритуальы, духи

\section{Введение}

Афрогенные религиозные традиции Кубы успешно пережили несколько эпох: рабовладельческую, когда существовала единственная официальная религия - римский католицизм, республиканскую, когда темнокожее население острова вместе с его традициями воспринималось как “отсталое”, “варварское”, “безграмотное”, и революционную эпоху, открытую Фиделем Кастро в 1959 году - эпоху, которая боролась с расизмом, но также и с религией (Лаврецкий 1967: 27-84). Хотя социализм продолжает существовать на Кубе, в конце XX - начале XXI вв. кубинское общество серьезно преобразилось, отчасти под воздействием тяжелой экономической ситуации, в которую Куба попала с распадом СССР и социалистического лагеря, отчасти под воздействием внутренних факторов. Одним из итогов так называемого специального периода в мирное время (el periodo especial en tiempos de paz, 1991-1995 гг.) стало официальное признание народной медицины и легитимация профессии травника (йерберо). Параллельная экономическим и медицинским реформам либерализация в сфере религиозной жизни привела к социальной эмансипации афрогенных культов: из музыкально-танцевального, фольклорного наследия они превратились в одну из движущих сил общества. Со временем афрогенные культы с их яркими ритуалами и образами стали важной составляющей туризма, бюджетообразующей отрасли государства. Общественный статус сантерии сильно вырос в начале XXI в.,

Маничкин Нестор Александрович - к.и.н., научный сотрудник, Институт этнологии и антропологии РАН (119991 Москва, Ленинский пр., 32а). Эл. почта: nes.pilawa@gmail.com. Manichkin, Nestor A. - PhD in Hist., Institute of Ethnology and Anthropology RAS (Moscow, Russia). E-mail: nes.pilawa@gmail.com. ORCID https://orcid.org/0000-0001-9308-0094

* Публикуется в соответствии с планом научно-исследовательских работ Института этнологии и антропологии РАН 
и посещение жрецов этого культа перестало считаться антисоциальным явлением (Gold 2014). Власти больше не препятствуют религиозной жизни кубинцев, а таковая включает в себя самого разного рода практики, в том числе и целительские.

Религиозная картина Кубы - довольно сложная. Помимо католицизма и мировых религий на острове распространено несколько религиозно-магических традиций африканского происхождения. В данной статье речь пойдет преимущественно о двух таких наиболее значимых традициях, имеющих этнические корни (сантерия и пало), а также о кубинском спиритизме, внутри которого вместе с европейским спиритическим учением и оккультизмом соседствуют африканские элементы, причем в некоторых случаях последние явно доминируют. Следует иметь в виду, что, помимо сантерии (также известной как регла де оча) и пало (пало монте, регла де пало), на Кубе действуют другие афрогенные культы: муэртера бембе де сао (сильно африканизированный спиритизм), арара (традиция, берущая происхождение от народов группы фон) и родственное этой традиции вуду, практикуемое преимущественно представителями обширной гаитянской диаспоры. Отдельно можно упомянуть абакуа, мужское тайное общество, деятельность которого включает осуществление обрядов, пришедших из культуры ряда африканских народностей: эфик, игбо, ибибо и других. За последние двести лет все эти культы в значительной степени сплелись друг с другом, причем в роли религиозного лингва франка для них выступил народный католицизм с его пантеоном святых: святые были отождествлены (или синкретизированы, как принято говорить) с духами афрогенных культов, которые составили таким образом большой сводный пантеон сакральных сил различного происхождения. К этим силам за исцелением и укреплением здоровья и обращаются приверженцы культов.

\section{Терапевтические церемонии афрогенных культов Кубы}

Сантерия остается наиболее известным и репрезентативным афро-кубинским культом. К ней примыкает культ божества Ифа, одного из оришей - сущностей, которых традиционно почитают среди йоруба в Нигерии и ряде сопредельных стран. Культ всеведущего Ифа осуществляют жрецы бабалао, а в сантерии жреческую роль исполняют бабалоча (жрецы-мужчины) и ийялоча (жрицы). При этом религиозный статус бабалао выше, чем статус жрецов сантерии. И бабалао, и сантеро (адепты сантерии) могут общаться с любыми оримами, но один из их пантеона является оришей-родителем (или «головным» оришей) человека, ангелом-хранителем, как говорят сами верующие, используя христианский вокабулярий. Сантерия хранит значительный объем знаний в области травничества: лес для сантеро священен и представляет живой храм, населенный различными духами (Cabrera 2018; Bolívar Aróstegui 2017). Тоже можно сказать о пало, последователи которого (палеро) развивают практики, уходящие корнями в культуру народов банту. Палеро взаимодействуют с сущностями нкиси и мпунгу, которые соотносятся с теми или иными ориша. Кубинцы различают специфику в духах пало и сантерии, но обычно наделяют тех и других соответствующими католическими атрибутами наряду с атрибутами африканского или местного происхождения. Для пало и сантерии характерен особый акцент на общении с умершими (нфумбе, бакула в пало, эггуны в сантерии), причем если сантеро обращаются преимущественно к предкам, то в пало широко развито использование “опасных”, неупокоенных духов. 
Господствует мнение, согласно которому в сантерии больше религиозного, а в пало больше колдовского. Обе традиции активно занимаются целительством. Очень часто диагностирование происходит в состоянии одержимости (posesión), когда духи устами своих служителей рассказывают о том, чем болен или чем может заболеть человек, что ему предпринять, какие лекарства использовать. Сантеро применяют также гадательную систему, известную как дилоггун, а бабалаво - оракул Ифа (Bolívar Arostegui 2018). Более простые системы (оби в сантерии и чамалонго в пало) в свою очередь сопровождают сами обряды, через эти оракулы выясняется, принято ли жертвоприношение, совершено ли очищение, довольны ли духи.

Существует большое количество терапевтических церемоний. Одна из наиболее распространенных - kawori eleda или rogación de cabeza, что можно примерно перевести как “очищение головы” или “освящение головы”: действо преследует своей целью сбалансировать трансцендентную силу ори (ori), которая содержится в голове каждого человека. Ори необходима защита и подпитка со стороны эледы (eleda), того ориша, который индивидуально связан с субъектом обряда. Этот ритуал, который мне удалось неоднократно наблюдать и проходить, может выполняться для разных целей: в качестве очищения перед инициациями, для отведения порчи или беды, удовлетворения духов, изгнания болезней и предотвращения несчастья. В нем используются кокосы, свечи, белая повязка или платок для головы (иногда белая кепка), хлопок (или вата), масло какао, две белые тарелки, вода (чаще освещенная из церкви или речная), ритуальный мел каскарийя (cascarilla), сделанный из скорлупы куриных яиц, и другие вещи. Существуют особые разновидности обряда с использованием рыбы, называемой pargo rojo (Lutjanus campechanus или Кампечинский луциан, рыба из отряда окунеобразных), которую определенным образом разделывают: голова рыбы и хвостовой плавник помещаются на голову человека, очищаемого во время kawori eleda, а другие части используются в соответствии с указанием оракула. Если обычные церемонии rogación de cabeza может проводить бабалоча, то те, в которых используется тушка рыбы, проводит бабалао. Обряд совершается вечером, обычно перед сном. Человек, на голову которого с песнопениями и бросанием оракула оби помещается смесь веществ, спит с ней, а рядом с ним на белых тарелках горят свечи. Он также должен искупаться в специальных жидкостях.

Различные омовения и купания чрезвычайно распространены в сантерии и пало. Это могут быть как обрядовые купания в реке, так и купания в ванной, куда выливаются мёд, алкоголь, настои растений, сыпятся лепестки цветов. Рецепты этих составов весьма разнообразны и могут определяться также посредством оракула. По словам информанта Я., молодого спирита и палеро, живущего в Гаване, ванные с горькими травами обычно готовят для отторжения отрицательных воздействий или злонамеренных духов, а ванные со сладкими травами для привлечения удачи и исцеления. Такие ванные могут чередоваться, а курсы омовений включать определенное количество дней, соотносящееся с числом того духа, силы которого привлекаются. С числом духа могут увязываться и дозировки ингредиентов. К примеру, один из рецептов очистительной ванны, призванной защитить человека силой ориши Бабалу Айе, включает кокосовое молоко, речную воду, сухое вино, мелассу и 17 капель одеколона (ПМА 2019).

Часто для омовений используется специальная, ритуально приготовленная смесь растений, воды и других веществ, известная как омиеро. Омиеро применяется во всех значимых обрядах сантерии, и, хотя это часть традиции йоруба, оно исполь- 
зуется также многими палеро. Впрочем, в пало жидкость, изготавливаемую похожим образом, называют не только омиеро, но и kimbanza, mbumbal mumba, lango de Ngurunfinda (вода Нгурунфинды) - терминами из киконго. Об омиеро на Кубе ходят легенды. Искусно сделанное омиеро якобы может спасти здоровье и жизнь в самых трудных ситуациях. Такие случаи описывает последователь и исследователь сантерии Р. Канисарес (Canizares 1999: 98-100).

Свежесобранные растения применяются также в процедурах decnoxo (despojo, изъятие, отбрасывание). Жрец бьет и обмахивает человека пучком таких растений, сгоняя с него отрицательных сущностей, отметая болезни и неудачи. В деспохо могут быть задействованы растения одного вида, либо нескольких. В чистках такого рода часто используют цветы белого цвета. Через пучок растений на человека могут пускать струи табачного дыма, орошать его алкоголем. В конце обряда цветы скручиваются, ломаются и бросаются на землю. Похожим образом происходит и чистка с помощью кокоса перед нгангой, главным алтарным объектом в пало, который обычно представляет собой котел, заполненный множеством специфических ингредиентов. Кокос натирают каскарийей, проводят им по телу человека с песнопениями, затем распыляют на кокос алкоголь, окуривают его сигарой и оставляют на некоторое время перед нгангой. После этого кокос уносят в место, которое указал оракул чамалонго (перекресток, кусты, кладбище и др.) (ПМА 2019). Не менее распространены и чистки с помощью свертков, в которые входят самые разные ингредиенты (связанные с теми или иным духом). Этими свертками также обмахивают человека, затем держат их в алтарном пространстве, а потом относят в определенные места.

Совершая перед теми или иными святынями жертвоприношения животных (церемонии кормления духов кровью), участники также прикасаются к ним, проводят птицами по телу, прежде чем их убить. Такие прикосновения могут, как считается, убрать от человека нечто негативное, придать ему силы и здоровья. Существуют и специальные практики заместительных жертвоприношений (el cambio de vida, nодмена жизни), когда духам вместо жизни больного человека предлагают жизнь животных (в некоторых колдовских практиках смертельную болезнь «перемещают» не на животное, а на другого человека). После очистительных церемоний мясо пожертвованных животных никогда не едят. Части жертвенных животных, иногда специальным образом приготовленные, вместе с другими ингредиентами могут входить в так называемые эббо (ebbó) - подношения духам, которые делаются с разными целями, в том числе и с целью избавления от болезней. Одно из самых распространенных

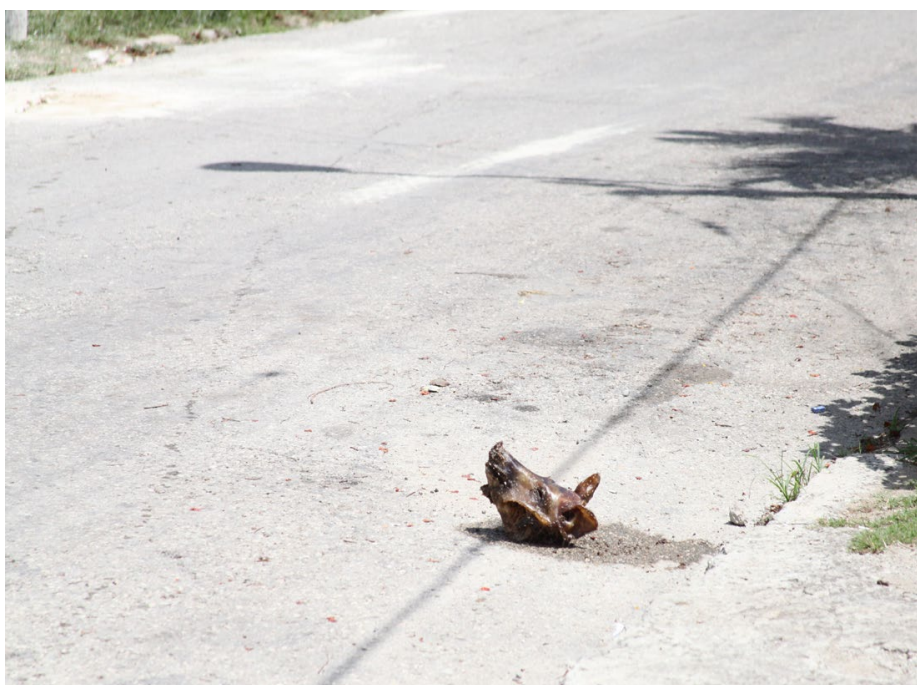

Рис.1. Подношение духам предков, свиная голова на перекрестке, Гавана (фото автора, июнь 2019 г.). 
эббо - поднесение эггунам свиной головы. Такие головы можно регулярно видеть на гаванских перекрестках, причем часто они лежат на терракотовой посуде вместе с приготовленным без соли супом ахиако (ајіасо).

Что касается спиритизма, то его практики редко включают в себя использование животных, зато очень часто в обрядах задействуются растения. Спиритизм, прошедший ряд трансформаций, принял на Кубе весьма своеобразные формы. Это неоднородное явление: часть спиритов тяготеют к так называемому научному спиритизму (espiritismo cientifico), а другая часть осуществляют свои практики в рамках креолизированного спиритизма крусадо, то есть перекрестного, смешанного (espiritismo cruzado). Представители первого направления используют такие термины как «метаболизм», «соматизация», «духовная система» и часто рассматривают африканские магические практики как небезопасные, излишне «материализованные», не обладающие интеллектуальной подготовкой и слабые в этическом отношении (Espírito Santo 2015: 152). Среди практиков espiritismo cientifico попадаются представители интеллигенции, инженеры и врачи. Те же спириты, которых можно отнести к espiritismo cruzado, зачастую одновременно являются приверженцами афрогенных культов, спокойно относятся к колдовским обрядам и животным жертвоприношениям и даже могут осуществлять таковые непосредственно в рамках спиритических практик, например, при создании спиритических кукол (Маничкин 2020).

Спириты разных направлений используют разработанные французским мыслителем и духовным деятелем Аланом Кардеком (1804-1869) молитвы и проводят церемонии, называемые духовнылми мессами (misa espiritual), на которых медиумы в измененных состояниях сознания передают людям вести от духов, устанавливают свою версию происходящего в жизни человека, проводят целительские манипуляции, дают советы. Духовные мессы включают в себя множество молитв, песнопений, зажжение свечей и окуривание алтаря (так называемой спиритической боведы, bóveda espiritual), омовения и очищения, танцы, но главным на них остается общение с духами через медиумов. Эти мессы в понимании спиритов могут менять не только жизнь людей, участвующих в церемониях, но и положение духов в загробном мире: по выражению одного из моих информантов, духов можно «приближать, отдалять, возвышать, помогать им найти свой путь и новое перерождение, отпускать» или, наоборот, «сгущать», т.е. приближать их к «физическому плану», плотнее связывать их с живыми людьми и земными, посюсторонними объектами (ПМА 2013).

\section{Ориши, грозные и милосердные}

К оришам, связанным со сферой здоровья, тяжелыми заболеваниями и смертью, относятся Ойя (покровительница ветров и хозяйка кладбищ), Обба (гордая ориша, олицетворяющая честь и преданность), Йева (покровительница нравственной чистоты, ориша-девственница, хозяйка могил), Нана Буруку (ориша-старуха, колдунья и покровительница болот), Айе Чалуга (ориша прибыли и здоровья), Инле (андрогинный ориша-змей, владеющий секретами целительства и магии) и в особенности Бабалу Айе или Асохано (ориша, заведующий инфекционными и иными тяжелыми заболеваниями, покровитель страждущих и скитающихся).

Культ Бабалу Айе имеет истоки в Западной Африке, где данное божество известно, прежде всего, как хозяин оспы. Ужасающий характер Бабалу Айе несколько смяг- 
чился на Кубе, в особенности благодаря его синкретизации с католическим Святым Лазарем, а точнее с двумя библейскими Лазарями - больным бедняком в струпьях из притчи Иисуса и Лазарем из Вифании, который был воскрешен и впоследствии стал епископом. Несмотря на тесную связь с христианскими образами, верующие обычно робеют перед ориша Бабалу Айе, а с медиумами, в которых он вселяется, никогда не шутят, опасаясь навлечь гнев властителя болезней. Жрецы сантерии во время одержимости Бабалу Айе могут вылизывать раны страждущих, и такая процедура считается исцеляющей (Cabrera 2018: 46). Интересно, что именно этому орише последователи сантерии в США (в основном, это - этнические кубинцы) устроили моления во время пандемии covid-2019, прибегнув к такому инструменту как флешмоб (Instagram 2020).

Культ Бабалу Айе - важная часть сантерии и арара, а в вуду его аналогом считают Легбу Пье или Сабату. В пало с Бабалу Айе и католическим Святым Лазарем синкретизирован Кубайенде (Мабиалана, Тата Лулено, Пунгун Футила, Тата Нфумбе), во власти которого находятся не только ужасающие болезни, но и мертвецы (Bolívar Aróstegui 2017: 314-320). Кубайенде сопровождает души умерших из нашего мира в загробное царство. Подобно тому, как Лазарь - единственный воскрешенный в Библии человек, Кубайенде - «единственный, кому удалось вернуться после смерти» (Ochoa 2010: 282-283). Именно эта пограничность наделяет его возможностью исцелять людей, пораженных смертельными заболеваниями.

В образе Кубайенде угадывается также родство со святыми подвижниками, веру которых Бог испытывал различными страданиями. По одной из легенд, распространенных на Кубе, Нсамби (Всевышний) и Луканкаси (дьявол) однажды поспорили о том, что на земле нет никого, кто сохранил бы верность Богу в тяжелых условиях. После этого Луканкаси (а по другой версии сам Нсамби) наслал на Кубайенде множество болезней, которые сделали его плоть заживо гниющей. Луканкаси предлагал исцеление Кубайенде взамен на отступничество от Нсамби, но тот трижды отказался, после чего Нсамби исцелил своего преданного последователя и наделил его властью врачевать людей. Поскольку Кубайенде синкретизирован с Бабалу Айе и Асохано, о нем также говорят как о короле из Дагомеи, который в своей жизни подвергался изгнанию и унижениям. Распространена легенда, согласно которой Бабалу Айе был убит Обаталой за нарушение одного из многочисленных табу, но потом был воскрешен по многочисленным просьбам женщин: дело в том, что Бабалу Айе в своем первом воплощении был очень красивым. После смерти Бабалу Айе предстал совсем другим: его тело было изуродовано струпьями и гниющими язвами, он хромал. Люди с отвращением и страхом прогнали Бабалу Айе, и он проклял их, наслав различные заразные болезни. Этот сюжет заканчивается тем, что люди каются перед оришей и получают его прощение, а вместе с таковым и исцеление (ПМА 2019).

Главным центром культа Бабалу Айе является город Ринкон, в котором располагается церковь Святого Лазаря. Верующие регулярно осуществляют паломничества в это место, приносят там обеты, проводят обряды (Zamora 2000). Мои полевые наблюдения в Ринконе и Гаване (в 2013 и 2019 гг.) позволяют говорить о чрезвычайной популярности синкретического культа Бабалу Айе в народе. Информанты, совершающие регулярные паломничества в Ринкон, сообщают, что неисполнение обетов, данных Бабалу Айе, грозит не только возвращением болезни, от которой они избавились, но и куда более страшными карами. Особым образом связанные с Бабалу Айе паломники заходят в церковь босиком, а расположившимся неподалеку 


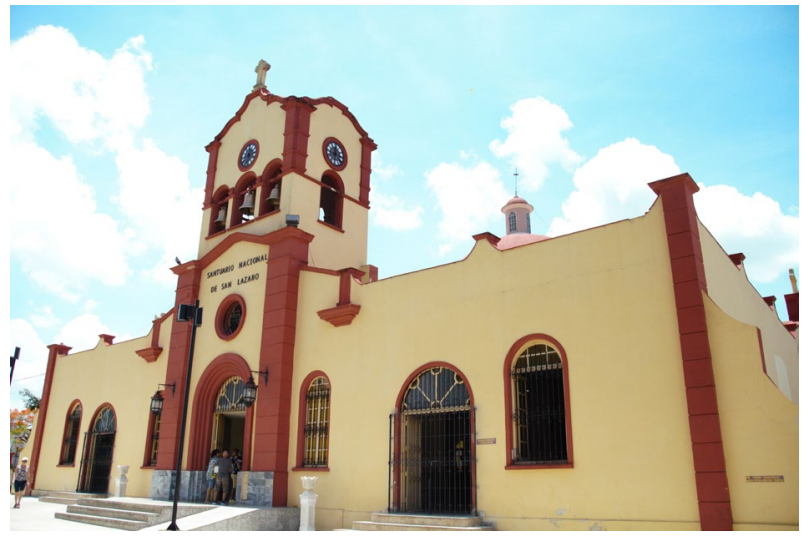

Рис. 2. Церковь Святого Лазаря, г. Ринкон, Куба (фото автора, июнь 2019 г.). от нее нищим (эта категория граждан находится под покровительством Бабалу Айе - Святого Лазаря) раздают милостыню. Один из моих информантов, кубинец по происхождению, бабалао, живущий в России, всегда посещает Церковь Святого Лазаря в Ринконе, когда отправляется на родину, причем, иногда он едет туда сразу по прилету, прямо из аэропорта, перед тем как поехать в свой гаванский дом (ПМА 2019).

Гнев ориш может выражаться в том числе в насылании болезней на своих проштрафившихся поклонников. Хотя ориши властны насылать любые болезни, есть те, которые наиболее характерны для каждого из них. Бабалу Айе поражает гангреной, проказой, различными инфекционными заболеваниями, включая венерические. Ориша мудрости и социальной справедливости Обатала, обычно мягкий по характеру, если его все-таки прогневать, может привести к параличу и слепоте. Психические болезни насылают Йева, Обба и Инле. Так называемые ориша-воины, Огун, Очоси и Элеггуа, устраивают кровотечения и бросают своих жертв умирать в одиночестве. Болезни, насылаемые громовержцем и божественным танцором Чанго, включают в себя жар или ожоги. Ойя поражает, если не молнией, то электрическим током, но может вызывать и болезни, связанные с органами дыхания и нервной системой. Водные ориши Очун и Йемайя разят в органы желудочно-кишечного тракта и мочеполовую систему (Cabrera 2018: 60-61).

Разумеется, ориши не только наказывают, но и лечат. Обращения к ним, очищения перед их святынями и в местах, которые ассоциируются с их властью (одни ориши предпочитают лес, другие водоемы, третьи кладбища), способны, как полагают последователи сантерии, отвести беду, избавить от тех или иных проблем. Зачастую назначая терапию в виде различных церемоний, жрецы объясняют своим клиентам, какой именно ориша гневается, какой в настоящее время покровительствует, и почему это происходит. Колдовские порчи - далеко не единственная причина болезней. Куда чаще в немилость ориш люди попадают из-за собственных промахов: нарушения табу, неправильного образа жизни, кощунства, долгов перед высшими силами, асоциального поведения.

\section{Спиритуальная феноменология здоровья: духи, свет и энергия аче}

Последователи сантерии верят в пронизывающую мироздание силу под названием аче. Это своеобразная энергия, дающая всему сущему движение. Хотя эта энергия безлична, у нее есть высшая квинтэссенция - верховное небесное божество Олорун. Согласно религиозной традиции йоруба, на заре творения сила аче спустилась в мир в виде королевского питона, габонской гадюки, дождевого червя, белой улитки и дятла. Аче мыслится как нейтральная жизненная сила, вибрация, приводящая в движение весь 
мир (Thompson 1984: 5-9). Аче можно сравнить с полинезийской маной, китайской ц̧и, ведической праной и т.п. Недостаток энергии аче или неправильное ее течение нарушает гармонию и может вызывать болезни. В ритуальных текстах сантерии и культа Ифа фигурируют пожелания аче всем живым жрецам и жрицам общины (ПМА 2013).

Дисгармония в отношениях людей друг с другом, миром, духами предков и оришами ведет к тому, что благие силы, называемые ире (iré), слабеют, а негативные силы, называемые осорбо (osorbo), берут верх. Бытие состоит из динамически меняющихся соотношений ире и осорбо, и важно правильно поддерживать равновесие, чтобы власть над человеком не взяли негативные силы. Одна из этих сил - болезни, нездоровье. Для обозначения этой разновидности осорбо используется ряд терминов африканского происхождения: arun, aro, oigu, yari-yari (Cabrera 2018: 29). Другие глобальные силы осорбо: еуо (зависть), ofo (потери), fitibo (препятствия) и т. д. Над негативными силами возвышается смерть Ику (Ikú), прожорливое, всегда враждебное людям существо, которое нападает на всех подряд, когда ему вздумается, но не трогает до соответствующего срока тех, кто имеет начальную инициацию в культ Ифа, поскольку Ифа (Орунмила), как считается, это - единственный ориша, которому удалось договориться со свирепым Ику и ограничить приносимые им разрушения. В отличие от «погребальных ориш», таких как Ойя, Йева, Бабалу Айе, Ику - не ориша, в нем нет ничего благого, у него нет своего культа или воплощающих его сакральных объектов. Сыновьями Ику иногда называют Таu, персонофицирующего головную боль, Avuvo, персонифицирующего лихорадки, и Arun, в образе которого собраны остальные хвори. Arun как болезнь может иметь различную специфику, быть врожденным заболеванием (arun anodi), не поддающейся определению болезнью (arun intikusara), болезнью, нанесенной при помощи колдовства (arun ogguo) и т. д. Во время регулярных религиозных церемоний последователи сантерии просят избавить их от еуо, ofo, arun и других неприятностей (bogbo osorbo - всех видов осорбо) и ниспослать различные виды ире.

Во время прорицания сантеро и бабалао устанавливают актуальную для клиента разновидность осорбо и предписывают ему те или иные действия, церемонии, табу и манипуляции, призванные сообщить ему силу аче и привлечь различные виде ире, включая iré ariku, хорошее здоровье и долгие годы жизни. Обычно прорицание устанавливает, чего от страждущего человека хотят ориши и эгzуны: подношений (aддимy), жертвоприношений (эббо), соблюдения запретов и ритуально обусловленного поведения или чего-то еще. Бабалао толкует ответы оракула, в которых могут содержаться самые разные рекомендации, включая рекомендацию обратить внимание на те или иные органы, обратиться к врачу, сдать анализы.

В дополнение к аче важен также свет, который, впрочем, многими считается разновидностью аче. Свет последователями сантерии, пало и особенно спиритами мыслится как особого рода сущее, благодаря которому можно налаживать гармоничные отношения между духами и людьми. Когда на алтарях зажигают свечи, то дают этим самым своим святыням силу - ориши, эггуны или нфумбе, обитающие в святынях, получают свет как подношение. Если речь идет о мертвых, то им свет нужен для того, чтобы эволюционировать в своей загробной жизни, обретая тем самым просвещенность, мудрость и новые силы. Силы духов, таким образом, находятся в интерсубъектной связи с действиями их поклонников. Свет особенно нужен «темным духам» (души колдунов, жертв убийств, преступников, самоубийц и т. д.), но, если в спиритиз- 
ме духов принципиально стараются просвещать и возводить на более высокие уровни бытия, то в пало духи нфумбе получают свет как бы дозированно, в первую очередь в обмен на их услуги в колдовстве. Многие палеро держат свои нганги в темных местах. Тем не менее, идея постмортального развития нфумбе существует и в пало.

Свет, который содержится в мощных и благих духах, может быть направлен в обратную сторону - на человека. Многие спириты, особенно те из них, что интересуются эзотерикой, формулируют свой опыт лечения как лечение «космическим светом». Души людей, с которыми сталкиваются медиумы-спириты, не только лечат. Ряд спиритов поддерживает идею о возможности не намеренной передачи со стороны духов своих болезней и травм людям. Кроме гнева ориш или злых козней темных духов человек может быть подвергнут нечаянному негативному влиянию нейтральных или доброжелательно настроенных сущностей. Считается, что непроработанные травмы «прописываются» в духовной части человеческого существа и остаются с ним после смерти. Такие духи могут «заразить» человека, с которым они вошли в общение, своими негативными состояниями. Обычно говорится о психических травмах, маниакальных или депрессивных состояниях, однако это влияние «больных духов» может привести и к физическим болезням и даже к смерти. Особенно опасными считаются духи, которые не осознают своей смерти, поскольку такие духи интенсивно стремятся к близости с живым человеком. Среди травм духов могут быть и коллективные травмы, вызванные войнами, насилием, депортациями. Работая со страждущим человеком, медиум может объяснить некоторые его состояния влиянием коллективных травм, которое исходит от душ покойников. Тогда процесс духовного исцеления и успокоения приобретает своеобразные психоаналитические черты. Спирит проводит работу для исцеления не только людей, которым духи передали свою травматичность, но и самих духов. Эти духи получают cвет, находят свое место или принимают себя и свою травму в мире ином, а человек, на которого они влияют, посредством подобной имагинации избавляется от каких-то своих проблем либо осмысляет их в свете спиритической картины мира и учится с ними жить (Espírito Santo 2015: 146). В таком процессе нетрудно обнаружить символические способы выстраивания экзистенциально значимой реальности.

Л., женщина среднего возраста, рассказывает, что несколько лет мучилась бессонницей. Успокоительные средства, прописанные врачами, а также народные средства (травяные сборы) ей не особенно помогали. Однажды Л. пришла с подругой на спиритическую мессу, и к ней неожиданно устами спиритки обратились духи. Выяснилось, что в спиритическом окружении Л. находится беспокойный дух человека, умершего во время войны за независимость Кубы. Этот человек был убит на боевом посту, когда уснул. Дух мужчины до сих пор не осознавал своей смерти, однако испытывал вину за то, что спал на службе и пропустил вражеский отряд. Л. вспомнила, что часто, когда ей удается уснуть, она видит военные сцены и массовое насилие. В то же время сама Л. мучилась чувством вины за ряд совершенных ею поступков. Еще одним духом, «прицепившимся» к Л. был дух юноши, пытавшегося нелегально эмигрировать из Кубы в США, через Флоридский пролив. Этот юноша якобы утонул. Работа спиритов с выявленными «травмированными» духами длилась почти год, и постепенно режим сна у Л. выровнялся. Через включенность в спиритуальную реальность травмированных сущностей она смогла расширить и укрепить свою самость, свое эго. Кроме того, Л. увлеклась спиритизмом и афро-карибскими культами (ПМА 2019). 
Если спиритические мессы, благодаря которым люди получают знания и благословения добрых духов, а страдающие или непросвещенные духи получают «свет» и «возвышаются», строятся вокруг травм, имеющих социально-историческую подоплеку, то эти церемонии можно считать своеобразной работой с исторической памятью и коллективными идентичностями. Таким образом, можно говорить о социальной медицине спиритизма, которая исходит из того, что тело человека является субстратом-инструментом в метаболизме глобального мира, где сосуществуют множество взаимопроникающих агентностей: человеческих, животных, спиритуальных. Болезнь при этом воспринимается в контексте широких социально-политических - а параллельно тому вселенских, мифопоэтически конструируемых - процессов (Espírito Santo 2015: 152-154). Отмечается, что афро-кубинские спириты своими духовными практиками успешно укрепляют веру людей в свои силы, оказывают положительное психотерапевтическое влияние, способны примирить человека с самим собой, помочь ему конвертировать свои проблемы в живой духовный формат, с которым производится работа, направленная на обретение новых смыслов и стимулов (Espírito Santo 2019).

\section{Медиумы и жрецы под грузом духовного избранничества}

Человек, имеющий способности к общению с духами усопших, на Кубе называется муэртера (тот, кто связан с мертвыми). В ходу для обозначения таких людей также понятия медиум и спирит (espiritista). Их способности именуются медиумичностью (mediumidad). Обретение mediumidad обычно сопровождается болезнями или экстраординарными событиями в жизни человека. Особенно распространены истории-воспоминания, когда обретший свою самость, нашедший себя медиум вспоминает, что впервые о своих способностях он заподозрил давно, например, еще в детстве, но не принял их по тем или иным причинам. Вариант нарратива: человек рассказывает, что только теперь осознал истинную подоплеку различных явлений и событий в своей жизни, а раньше не понимал, что происходит. Это «повторное открытие» медиумичности происходит, как правило, в сложных условиях, когда под угрозой находится физическое и эмоциональное благополучие человека, а боль и растерянность угрожают его личностной целостности.

Видения, ощущения и нежелательные переживания одержимости вызывают тревожную реакцию, провоцируют поиск объяснений происходящего и путей облегчения. Здесь на помощь обычно приходят опытные спириты и сантеро, которые через включение страждущего человека в духовные практики останавливают распад его эго на «непрочные миры» и производят пересборку самоидентификации. Элементами этой пересборки выступают все те же духи. Потому исследовательница кубинского спиритизма Д. Эспирито Санто подчеркивает, что самость человека в спиритической перспективе парадоксальным образом одновременно едина и множественна (Espírito Santo 2015: 160).

Не только духи мертвых (эгzуны), но и ориши с помощью различных недугов могут указывать на то, что выбрали того или иного человека для духовного служения (Moret 2008: 345). Известность получила история кубинца Энрике, у которого были парализованы ноги. Он передвигался в инвалидной коляске, и врачи не оставляли ему больших надежд на восстановление. Однако ориша Элеггуа предложил Энрике 
сделку: возвращение ему способности передвигаться в обмен на то, чтобы тот стал его медиумом. Энрике выздоровел, стал известным духовным практиком и работал не только на Кубе, но и в других странах. До самой его смерти в 2009 году ему помогали Элеггуа и еще 121 дух-помощник (Espírito Santo 2015: 161). Интересно, что передвижение, перемещение, способность миновать препятствия и переходить границы (в том числе путешествия в зарубежные страны, которые долгое время оставались недоступными большинству кубинцев) находятся в компетенции неусидчивого и вездесущего трикстера Элеггуа.

Х., двадцатилетний юноша, родившийся в г. Ольгин и живущий в Гаване, рассказывает, что его тётя долгое время страдала болезнью, в которой врачи видели эпилепсию. Жрецы посоветовали ей совершить инициацию кариоча, усаживание святого (или ориша) в голову человека, и стать сантерой. Предсказание показало, что болезнь женщины - это знак ее избранничества, а ее припадки происходят из-за неправильных попыток духов войти в ее тело. Став практиковать, она излечилась. Другая знакомая того же информанта долгое время не могла найти себе мужа, а те парни, с которыми она пыталась построить отношения, бросали ее, либо с ними происходили какие-то несчастья. Справиться с возникшей на фоне личных неурядиц депрессией и примириться с участью одинокой женщины ей удалось, опознав в своей судьбе вмешательство ориши Йевы, которая требует от некоторых своих последовательниц соблюдения безбрачия и целомудрия. Взамен женщина обрела способности к предсказанию (ПМА 2019).

Феномен вхождения духовных сил в жизнь будущего адепта называется acercamiento (приближение). В период приближения духи дают знать о своей воле порой преувеличенными и болезненными проявлениями физического порядка. Считается, что так они привлекают внимание избранника к его миссии и медиумическим способностям. Частые симптомы подобного духовного избранничества: тошнота, судороги, бессонница, двигательные, идеаторные и сенсорные автоматизмы. Кубинские медиумы порой описывают своих духов как сильных, грубых и неконтролируемых во время acercamiento. Первоначальные попытки этих духов «взять» тело могут быть неуклюжи и жестоки, особенно если дух “не образован”, например, был рабом при жизни, претерпел много жестокостей и страданий. Кроме того, сущности иногда передают своим референтам ощущение болезней, которыми страдали при жизни. Медиумы могут спутать такие симптомы с физическими болезнями, а это, по мнению практиков, приведет к бесполезному медицинскому вмешательству. В качестве примера можно привести историю медиума, которая чувствовала боль в груди из-за общения с духом своей бабушки, болевшей раком легких (Espírito Santo 2015: 162). Два моих информанта сообщали, что духи людей, бывших при жизни алкоголиками, требуют во время своих появлений выпивать большое количество алкоголя. Однако к алкоголизму самих медиумов это пока не привело (ПМА 2019).

Интересна история Леонеля, описанная Д. Эспирито Санто. Леонель в детстве страдал внезапными судорогами, постоянно проявлял беспокойство и не мог спать. Он родился и рос в семье приверженцев социалистических идей, считавших афрогенные культы проявлением безграмотности и отсталости. Врачи поставили Леонелю диагноз эпилепсия, однако прием лекарств не привел к заметному облегчению. Однажды пожилая женщина разъяснила отчаявшейся матери Леонеля, что ребенок выбран духами и должен обучатся спиритизму. Его было трудно заставить вклю- 
читься в спиритические практики, но по мере вовлечения в них Леонель стал выздоравливать. В дальнейшем он развивал свои спиритические навыки, а в 1979 году прошел посвящение в сантерию. По словам спиритов, наблюдавших Леонеля, одним из духов, который одержал его в детстве, был чернокожий раб Франсиско, много пострадавший в своей жизни и имевший не самый мягкий нрав. После инициации Франсиско и другие духи стали сопровождать Леонеля в его духовных практиках (Espírito Santo 2015: 163-165).

Инициации улучшают самочувствие не только у людей, призванных духами к ритуальному служению. Считается, что любой посвященный приобретает дополнительную защиту, возможности здоровья и процветания. Часто при этом говорится об иммунной системе, которая должна нормализовываться или активизироваться благодаря вхождению в жизнь человека эледы, головного ориии. Если человек болен или беден, и не может обеспечить затратную и долгую инициацию кариоча, требующую участия целого коллектива духовных лиц, работы барабанщиков, а также множества животных жертвоприношений, то он может «получить своего святого» и без присоединения ориши к ори (сознанию) человека, с помощью достаточно простой церемонии santo lavado (омовение святого). Такой человек не становится бабалоча или ийялоча, но он все же имеет особый «канал связи» с теми или иными оришами и может обслуживать их святыни. Какие именно ориши и каким именно образом должны войти в жизнь человека, устанавливают авторитетные жрецы при помощи прорицания.

\section{Невидимые доктора: диагностика и терапия духов}

Духи могут советовать своим медиумам, как и чем лечить те или иные заболевания. К примеру, Палоянсан, дух раба-гаитянина, ставший главным духом в спиритическом окружении медиума Марселины, излечил ее от болезни печени, сообщив рецепт целебного травяного отвара (Espírito Santo 2015: 285). Все “потусторонние врачи" в кубинском спиритизме объединяются в группу духов известную под названием Comision Médica divina (Божественная медищинская комиссия). Ее также называют Comision Médica divina de los espacios (Божественная медицинская комиссия космических пространств), подразумевая под еsрасіо космос, обитель духов, которых нередко именуют космическими собратьями (hermanos del espacio) (Cabrera 2018: 76). Для объединения врачующих духов существует также название Comisión Médica de San Rafael (Медuцинская комиссия Святого Рафаэля) (Alpizar 2019: 18). Главой сообщества духов-медиков называют либо Архангела Рафаэля, либо врача и героя войны за независимость Кубы, генерала Хуана Бруно Сайяса Альфонсо (18671896). О популярности личности последнего среди спиритов писала еще Л. Кабрера: ее информанты через запятую перечисляли африканских божеств, «апостола Марти» (Хосе Марти) и «бестелесного доктора» Сайяса (Cabrera 2018: 39).

В этом отношении показательна деятельность знаменитой гаванской спиритки и целительницы Пахиты ла Милагроса, с разрешения государства проводившей целительские приемы, на которых основная деятельность велась при помощи духа сестры Пахиты, женщины, при жизни работавшей врачом. Выступая перед общественностью, Пахита подчеркивала, что признает доказательную медицину и ни в коем случае не оспаривает действенность «официальных» фармакологических средств. Духи вообще нередко направляют обратившихся к целителям людей в больницу, а 
сами кубинцы зачастую предпочитают сочетать в своем лечении доказательную медицину с народной медициной и магией или духовным целительством (Espírito Santo 2015: 133-136). Иногда жители Гаваны обращаются к бабалао и спиритическим медиумам, чтобы перепроверить назначенный им курс лечения или усилить его. Даже купленные в аптеках лекарства могут стать объектом духовно-магической работы по их «усилению». Сантеро нередко обращаются к оришам с просьбой, чтобы они усилили эффект того или иного препарата. Если же член семьи сантеро попадает в больницу с острым течением болезни, его родственники стараются провести все необходимые обряды, направленные на помощь больному.

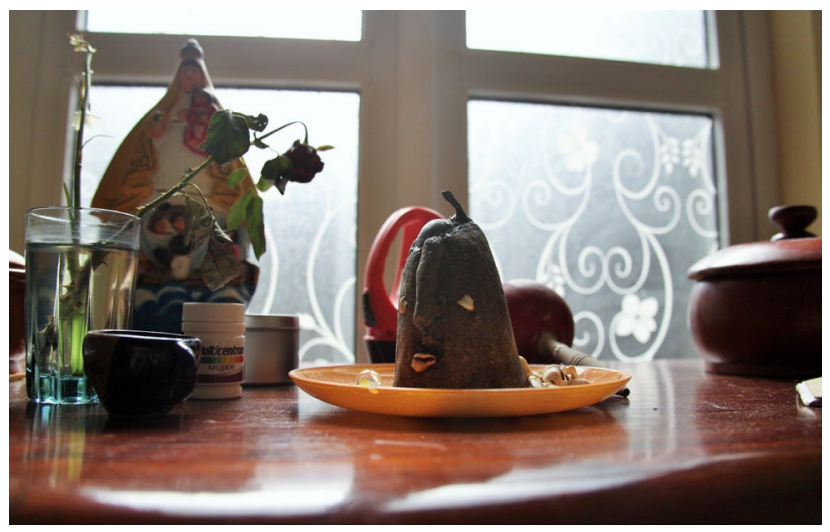

Pис. 3. Поливитамины для женщин «Multicentruт» получают дополнительную ијелебную силу на домашнем алтаре, рядом со святынями Элеггуа и Очун, Гавана (фото автора, июнь 2019 г.).

Существует и обратная связь, когда сами врачи ищут духовно-магических практик для себя либо неофициально направляют к знакомым медиумам и целителем своих пациентов (Potterf 2006: 87-88). Как показывают исследования, в настоящее время ни йерберо (травники), ни сантеро на Кубе не конкурируют с государственной медициной. Чаще всего серьезно болеющим они рекомендуют направиться к врачу (Wedel 2005: 50). Параллелизм в лечении порой обусловлен высоким доверием к тем или иным целителям, их умением, по меньшей мере, успокоить пациента и настроить его на излечение. «Я не знаю, что мне помогло, духи моей тети-спиритки или доктора из больницы. Я долго лечилась в больнице, но пока мы не получили благословения духов, это лечение не давало результата», - признается восемнадцатилетняя А., жительница Гаваны. По ее словам, только «отбросив вредных духов», она приободрилась, почувствовала себя увереннее и дала врачам возможность применить их арсенал. По словам А., иногда, «чтобы таблетки начали действовать, нужно получить разрешение предков или убрать то зло, которое мешает тебе, очистить свое духовное окружение» (ПМА 2019).

Связи между сообществами духовных практиков и медиков на Кубе не слишком сильны, и все же они есть. Особенно это касается так называемого научного спиритизма, который в большей степени, чем колдовской спиритизм крусадо, понятен и близок представителям врачебного сообщества. Существуют неофициальные терапевтические группы, в которые входят не только представители афро-кубинских традиций и спириты, но также психологи и психиатры. Такие коллективы действуют без одобрения властей, не имеют официальной регистрации, привлекают к своей работе представителей оккультных направлений, к примеру, астрологов (Espírito Santo 2015: 137-138). Несомненно, наблюдается влияние глобальных факторов на развитие целительских практик спиритизма и афрогенных культов Кубы. Их представители, имеющие доступ к литературе и СМИ, а теперь и к мировой паутине, все чаще пользуются понятиями из арсенала биоэнергетики, восточной эзотерики, йоги. 
Целительство при помощи духов занимает важную нишу в деятельности афро-кубинских религиозных традиций, таких как сантерия, культ нигерийскго божества мудрости Ифа, пало монте, спиритизм крусадо и других. Благодаря социальной эмансипации афрогенных культов, последовавшей после так называемого специильного nериода, верующие открыто проводят свои обряды. Довольно часто духовно-магические и религиозные практики сопутствуют биомедицинской терапии. Информанты отмечают, что сочетание биомедицинского и духовного лечения более эффективно и надежно. На Кубе нет конкуренции между доказательной медициной и религиозным целительством, но в то же время в народной среде считается, что специфические патоморфные состояния, означающие приближение того или иного духа (избранничество адепта, проявление медиумического дара), находятся в компетенции духовных лиц, а не врачей. В случаях, когда человек проходит через период болезненных испытаний и явлений и становится медиумом или жрецом, он обычно испытывает облегчение. К исключительной области духовного целительства также относятся случаи негативного влияния травмированных духов, своеобразные спиритуальные “заражения”. Они могут ограничиваться одной лишь симптоматикой без органических поражений, а могут, как полагают приверженцы культов, иметь и более серьезные последствия.

Инициации, в том числе главная инициация сантерии, известная под названием кариоча, по представлениям верующих, приносят оздоровительный и усиливающий эффект не только для тех, кого духи принудили следовать особому пути, но и вообще для всех, кто ищет защиты у высших сил. Такое представление обосновывается идеей о соединении индивидуального ориша-покровителя (эледы) с ори (сознанием, ментальностью) человека. Часто применяемый обряд чистки головы исходит из той же идеи, и нередко его проводят для оздоровления человека. Помимо этого обряда афро-кубинские традиции знают большое количество других, обычно включающих подношения (аддиму, эббо) тем или иным сущностям. Духовное целительство на Кубе тесно переплетено с травничеством, поскольку в растениях также присутствуют духовные силы и универсальная энергия аче. Различные растения и препараты на растительной основе широко применяются во всех афро-кубинских религиозных традициях.

Аче - основа спиритуальной феноменологии здоровья. Эта сила может быть приведена в нужное состояние путем определенных обрядовых манипуляций и коррекции поведения человека. Могущественными агентностями аче выступают различные духовные существа: ориши и эггуны сантерии, нкиси и нфумбе пало, различные духи спиритизма, арара, вуду и других традиций. Афро-кубинские традиции рассматривают живого человека в контексте его сложных связей внутри огромного, проницаемого мира сущностей, включая духов мертвых. Последние, как считается, могут вольно или невольно влиять на здоровье и самочувствие человека, причем травмы, которые остались у духов от их земной жизни, часто дают о себе знать при медиумической работе с этими духами. Идея о посмертном развитии духов, которая существует как в спиритизме, так и в африканской космогонии, делает возможной духовно-ориентированную терапию: человек способствует возвышению духов, “дает свет” им, а они посредством работы своих медиумов исцеляют человека. Подобные образы обмена можно обнаружить и в практиках одержимости, когда медиумы временно предоставляют свои тела духам, а духи, в свою очередь, делятся с людьми своими знаниями и целительской силой. 


\section{Источники}

ПМА 2013 - Полевые материалы автора. Экспедиция в Гавану и Ринкон, Республика Куба; декабрь 2013 г.

ПМА 2019 - Полевые материалы автора. Экспедиция в Гавану и Ринкон, Республика Куба; июнь 2019 г.

Instagram 2020 - Babalú ayé es un orisha especialmente temido y poderoso... https://www.instagram.com/p/B-uZTXjD-OR/ (дата обращения: 09.02.2020).

\section{Научная литература}

Лаврецкий И.Р. Боги в тропиках. М.: Наука, 1967.

Маничкин Н.А. Мама Франсиска: этнокультурная память в кубинском культе спиритических кукол // Этнографическое обозрение. 2020. № 1. С. 132-152.

Alpizar R. Diccionario Razonado del Léxico Congo en Cuba. Maiombe, 2019.

Bolívar Arostegui N. La sabiduría de los oráculos: ifa, los caracoles y el coco. La Habana: Editorial Jose Marti, 2018

Bolívar Aróstegui N. Los Orishas en Cuba. La Habana: Institutio cubano del libro editorial José Martí, 2017.

Bolivar Arosteguí N. Plantas medicinales y aromáticas // Revista Bimestre Cubana de la Sociedad Económica de Amigos del País. 2001. № 15. Pp. 47-63.

Cabrera L. El monte. La Habana: Editorial Letras Cubanas, 2018.

Cabrera L. La medicina popular de Cuba: Médicos de antaño, curanderos, santeros y paleros de hogaño. Miami: Colección del Chicherekú, 1984.

Canizares R. Cuban Santeria. Walking With In The Night. Vermont: Destiny Books, Rochester, VT, 1999.

Gold M. Healing Practices and Revolution in Socialist Cuba // Social Analysis. 2014. № 58 (2). Pp. 42-59.

Espirito Santo D. Developing the Dead. Miami: University Press of Florida, 2015.

Espirito Santo D. The making of spirit bodies and death-perspectives in Afro-Cuban religion // Articulate Necrographies: Comparative Perspectives on the Voices and Silences of the Dead / Ed. by A. Panagiotopoulos and D. Espírito Santo. 2019. Bloomington: Indiana University Press Indiana University Press, 2019. Pp. 85-105.

Moret E.S. Afro-Cuban Religion, Ethnobotany and Healthcare in the Context of Global Political and Economic Change // Bulletin of Latin American Research. 2008. № 27 (3). Pp. 333-350.

Ochoa T.R. Society of the Dead: Quita Manaquita and Palo Praise in Cuba. Berkely, Los Angeles, London: University of California Press, 2010.

Potterf T. The Future of Health in Cuba // Cuba: In Transition? Pathways to Renewal, Long-Term Development and Global Reintegration / Ed. by A. Mauricio. 2006. New York: Bildner Center for Western Hemisphere Studies, The Graduate Center, City University of New York, 2006. Pp. 83-94.

Thompson R.F. Flash of the Spirit: African \& Afro-American Art \& Philosophy. New York: Vintage Books, 1984.

Zamora L. El culto de San Lázaro en Cuba. La Habana: Fundacion Fernando Ortiz, 2000.

\section{References}

Alpizar, R. 2019. Diccionario Razonado del Léxico Congo en Cuba [Reasoned Dictionary of the Congo Lexicon in Cuba]. Maiombe.

Bolívar Arostegui, N. 2001. Plantas medicinales y aromáticas [Medicinal and aromatic plants]. Revista Bimestre Cubana de la Sociedad Económica de Amigos del País 15: 47-63.

Bolívar Arostegui, N. 2017. Los Orishas en Cuba [The Orishas in Cuba]. La Habana: Institutio cubano del libro editorial José Martí.

Bolívar Arostegui, N. 2018. La sabiduría de los oráculos: ifa, los caracoles y el coco [Wisdom Of The Oracle: Ifa, Snails and Coconut ]. La Habana: Editorial Jose Marti. 
Cabrera, L. 1984. La medicina popular de Cuba: Médicos de antaño, curanderos, santeros y paleros de hogaño [Cuban Indigenous Medicine: Doctors of the Past, Curanderos, Santeros and Paleros of the Present]. Miami: Colección del Chicherekú.

Cabrera, L. 2018. El monte [Weald]. La Habana: Editorial Letras Cubanas, 2018.

Canizares, R. 1999. Cuban Santeria. Walking With In The Night. Vermont: Destiny Books, Rochester, VT.

Espírito Santo, D. 2015. Developing the Dead. Miami: University Press of Florida.

Espírito Santo, D. 2019. The making of spirit bodies and death-perspectives in Afro-Cuban religion. In: Articulate Necrographies: Comparative Perspectives on the Voices and Silences of the Dead, edited by A. Panagiotopoulos and D. Espírito Santo, 85-105. Bloomington: Indiana University Press Indiana University Press.

Gold, M. 2014. Healing Practices and Revolution in Socialist Cuba. Social Analysis 58 (2): 42-59.

Lavretskii, I.R. 1967. Bogi v tropikakh [Gods in the Tropics]. Moscow: Nauka.

Manichkin, N.A. 2020. Mama Fransiska: etnokul'turnaia pamiat'v kubinskom kul'te spiriticheskikh kukol [Mama Francisca: Ethnic-Cultural Memory in the Cuban Cult of Spiritual Dolls]. Etnograficheskoe obozrenie 1: 132-152.

Moret, E.S. 2008. Afro-Cuban Religion, Ethnobotany and Healthcare in the Context of Global Political and Economic Change. Bulletin of Latin American Research 27 (3): 333 - 350.

Ochoa, T.R. 2010. Society of the Dead: Quita Manaquita and Palo Praise in Cuba. Berkely, Los Angeles, London: University of California Press.

Potterf, T. 2006. The Future of Health in Cuba. In: Cuba: In Transition? Pathways to Renewal, LongTerm Development and Global Reintegration, edited by A. Mauricio, 83-94. New York: Bildner Center for Western Hemisphere Studies, The Graduate Center, City University of New York.

Thompson, R.F. 1984. Flash of the Spirit: African \& Afro-American Art \& Philosophy. New York: Vintage Books.

Zamora, L. 2000. El culto de San Lázaro en Cuba [The cult of Saint Lazarus in Cuba]. La Habana: Fundacion Fernando Ortiz.

Manichkin, Nestor A.

\section{Spiritual Healing in Afro-Cuban Religious Traditions}

The article is devoted to spiritual healing and therapeutic ceremonies of Afro-Cuban religious traditions. Particular attention is paid to the complex relationships of worshipers with spirits. In this regard, the circumstances and signs of spiritual chosenness, the connection between initiations and healing, as well as general ideas about the structure of being, which are the basis of Afro-Cuban healing, are examined. The article is based on the author's field reserach and literature on the topic.

Keywords: Cuba, spiritualism, santeria, palo monte, Yoruba, healing, indigenous medicine, rituals, spirits 